\title{
PENGARUH PROFITABILITAS TERHADAP HARGA SAHAM \\ PADA PT TELEKOMUNIKASI INDONESIA TBK
}

\author{
Ajang Mulyadi \\ Heni Mulyani \\ Esti Istiyani
}

\begin{abstract}
This research aims to know the influence of profitability toward share price in PT Telekomunikasi Indonesia at 1998-2011 periods. Profitability is measured by indicator of return on equity (ROE) which can be seen from the financial statements have been published. The design in this research using a causal design which useful to analyze the relationship between two variables or how one variable affects another variable. While, the method used is descriptive verificative. Data analysis using correlation analysis techniques product moment. This research states that the coefficient of correlation is 0,259 . This rate shows that the profitability is positively associated with lower categories toward share price. And based on the calculation of the coefficient determination, it is known that profitability affect the share price of $6,71 \%$ and the residual of $93,29 \%$ affected by other factors outside the profitability. Thus, the hypothesis in this research received that a positive influential on the profitability toward share price. But, the influence is very lower until can say that just the profitability is not strong enough to get the measure in assessment share price.
\end{abstract}

\section{LATAR BELAKANG MASALAH}

Persaingan ketat yang terjadi saat ini telah membuat banyak perusahaan berinvestasi saham di pasar modal guna memenuhi kebutuhan permodalannya. Pasar modal merupakan salah satu sarana yang menghubungkan pihak yang memiliki kelebihan modal (investor) dengan pihak yang membutuhkan modal (perusahaan) dengan cara memperjualbelikan surat berharga (sekuritas). Salah satu surat berharga yang sangat populer di pasar modal adalah saham. Dengan demikian, investor dapat mengalokasikan modalnya dengan cara membeli saham perusahaan.

Salah satu alternatif untuk dapat melakukan transaksi saham di pasar modal adalah melalui pasar sekunder (bursa efek). Investasi saham ini merupakan investasi yang penuh dengan risiko karena harga yang diperdagangkan di bursa sangat fluktuatif. Harga saham ini merupakan indikator nilai perusahaan. Nilai perusahaan merupakan cara pandang atau persepsi investor terhadap perusahaan. Artinya, apabila terjadi kenaikan harga saham maka investor akan menilai bahwa 
perusahaan tersebut menguntungkan. Untuk itu, investor berkepentingan dalam menganalisis saham.

Harga saham PT Telekomunikasi Indonesia Tbk pada periode 2007-2011 ini berfluktuasi. Namun penurunan terjadi di tahun 2008, 2009, dan 2011. Penurunan ini akan berdampak pada penurunan nilai perusahaan sehingga dapat menyebabkan berkurangnya kepercayaan investor untuk menginvestasikan modalnya di perusahaan. Jika penurunan ini terjadi dalam waktu yang lama maka perusahaan akan mengalami kesulitan untuk memperoleh modal tambahan.

Fluktuasi harga saham dipengaruhi oleh banyak faktor, salah satunya adalah kinerja perusahaan. Untuk itu, teknik analisis yang digunakan untuk menganalisis saham ini menggunakan analisis fundamental. Kinerja perusahaan ini tercermin dari kinerja keuangannya. Aspek yang biasa digunakan investor untuk mengukur kinerja keuangan perusahaan adalah profitabilitas. Hal ini dikarenakan profitabilitas berkaitan erat dengan keuntungan yang diperolehnya. Profitabilitas adalah kemampuan perusahaan dalam menghasilkan laba.

Profitabilitas dalam penelitian ini diukur menggunakan indikator return on equity (ROE). Rasio ini mengukur efisiensi perusahaan dalam menggunakan modal sendiri untuk menghasilkan laba. Kelebihan ROE ini dibandingkan dengan rasio profitabilitas lainnya adalah dapat merefleksikan tingkat pengembalian yang berhak diterima investor atas investasi yang dilakukannya. Semakin besar ROE semakin baik. Artinya, semakin besar peluang untuk memperoleh pengembalian investasi sehingga investor semakin tertarik untuk membeli saham sehingga menyebabkan harga saham meningkat.

\section{RUMUSAN MASALAH}

Masalah dalam penelitian ini dapat dirumuskan sebagai berikut:

a. Bagaimana gambaran profitabilitas pada PT Telekomunikasi Indonesia Tbk periode 1998-2011

b. Bagaimana gambaran harga saham pada pada PT Telekomunikasi Indonesia Tbk periode 1998-2011 
c. Bagaimana pengaruh profitabilitas terhadap harga saham pada pada PT Telekomunikasi Indonesia Tbk periode 1998-2011

\section{TUJUAN PENELITIAN}

Adapun tujuan dari penulisan penelitian ini adalah sebagai berikut:

a. Untuk mengetahui gambaran profitabilitas pada PT Telekomunikasi Indonesia Tbk periode 1998-2011

b. Untuk mengetahui gambaran harga saham pada pada PT Telekomunikasi Indonesia Tbk periode 1998-2011

c. Untuk mengetahui pengaruh profitabilitas terhadap harga saham pada pada PT Telekomunikasi Indonesia Tbk periode 1998-2011

\section{KEGUNAAN PENELITIAN}

a. Kegunaan Teoritis (Akademik)

Hasil penelitian ini diharapkan dapat memberikan sumbangan pemikiran dan informasi yang berguna mengenai pengaruh profitabilitas terhadap harga saham serta dapat dijadikan referensi untuk perluasan penelitian selanjutnya terutama yang berkaitan dengan faktor-faktor fundamental yang mempengaruhi harga saham.

b. Kegunaan Empiris (Praktis)

Penelitian ini juga diharapkan dapat memberikan informasi bagi perusahaan mengenai pengaruh profitabilitas terhadap harga saham sebagai masukan untuk dapat meningkatkan harga sahamnya yang listing di bursa efek dengan meningkatkan profitabilitasnya yang dapat dilihat dari data laporan keuangan yang telah dipublikasikan.

\section{LANDASAN TEORI}

\section{A. Pengertian Kinerja Keuangan}

Kinerja keuangan menurut S. Munawir (2010:64) adalah "prestasi kerja yang telah dicapai oleh suatu perusahan dalam periode tertentu dan tertuang pada laporan keuangan yang bersangkutan.” Sedangkan Agnes Sawir (2005:1) 
mendefinisikan kinerja keuangan sebagai "kondisi yang mencerminkan keadaan keuangan suatu perusahaan berdasarkan sasaran, standar dan kriteria yang telah ditetapkan." Menurut Bambang Riyanto (2008:25), baik buruknya kinerja keuangan dapat dinilai dari beberapa aspek diantaranya:

1) Likuiditas

Likuiditas ini menunjukkan sejauh mana kemampuan perusahaan dalam memenuhi kewajiban jangka pendeknya atau yang harus segera dibayar. Jika perusahaan mampu memenuhi kewajiban jangka pendeknya maka dapat dikatakan bahwa perusahaan dalam keadaan likuid. Sebaliknya, jika perusahaan tidak mampu membayar kewajiban jangka pendeknya tepat waktu maka perusahaan berada dalam kondisi illikuid. Artinya, kondisi keuangan perusahaan tersebut dalam kondisi kurang baik dan dampaknya dengan segera perusahaan akan mengalami kesulitan keuangan.

2) Solvabilitas

Solvabilitas ini menunjukkan sejauh mana kemampuan perusahaan dalam membayar kewajiban jangka panjangnya atau membayar kewajiban saat perusahaan dilikuidasi. Suatu perusahaan dapat dikatakan solvable apabila perusahaan tersebut mampu membayar semua utangnya dengan aktiva yang dimilikinya. Sebaliknya jika jumlah aktiva yang dimiliki perusahaan tersebut tidak mencukupi untuk melunasi utangnya, maka perusahaan dapat dikatakan insolvable. Artinya, kondisi keuangan perusahaan dalam kondisi kurang baik dan dampaknya perusahaan tersebut akan mengalami kesulitan keuangan saat perusahaan dibubarkan.

3) Profitabilitas/Rentabilitas

Profitabilitas adalah kemampuan perusahaan dalam mendapatkan laba selama periode tertentu. Profitabilitas digunakan untuk menilai kesuksesan perusahaan dalam memperoleh laba dan mengukur efisiensi perusahaan dalam menggunakan aktiva atau modal yang dimilikinya, sama halnya seperti rentabilitas.

\section{B. Profitabilitas}


Menurut Agnes Sawir (2005:17) "Profitabilitas merupakan hasil akhir bersih dari berbagai kebijakan dan keputusan manajemen." Kemudian Agus Sartono (2009:122) mengemukakan bahwa "Profitabilitas merupakan kemampuan perusahaan memperoleh laba dalam hubungannya dengan penjualan, total aktiva maupun modal sendiri."

Biasanya investor tertarik untuk menganalisis profitabilitas perusahaan karena berkaitan dengan keuntungan yang diperolehnya. Seperti yang dikemukakan oleh Suad Husnan (2005:72) bahwa:

Pada umumnya, investor hanya melakukan analisis laporan keuangan dengan menggunakan analisis rasio profitabilitas dengan pertimbangan bahwa analisis rasio profitabilitas mengukur kemampuan aktiva perusahaan memperoleh laba dari operasi perusahaan.

Selain itu, Henry Simamora (2000:516) juga mengemukakan bahwa :

Para pemegang saham dapat memperoleh suatu hasil investasi dari deviden maupun dari hasil penjualan saham pada harga yang menanjak. Mereka ingin mampu memprediksi laba perusahaan di masa yang akan datang karena profitabilitas merupakan indikator terbaik kemampuan perusahaan membayar deviden dan nilai pasar saham perusahaan.

\section{Return on Equity (ROE)}

Menurut Moeljadi (2006:53) "Return on Equity menunjukkan kemampuan modal sendiri dalam menghasilkan keuntungan yang tersedia bagi pemegang saham.” Lebih lanjut, Suad Husnan dan Enny Pudjiastuti (2006:73) mengemukakan bahwa "Return on Equity mengukur seberapa banyak keuntungan yang menjadi hak pemilik modal sendiri."

Dalam perspektif investor, ROE merupakan salah satu faktor penting untuk menilai profitabilitas dan harga saham karena rasio ini mencerminkan tingkat pengembalian investasi yang dilakukan investor. ROE yang tinggi mencerminkan tingkat pengembalian yang tinggi pula. Apabila ROE meningkat maka permintaan akan saham akan meningkat dikarenakan banyak investor yang membeli saham perusahaan sehingga harga saham pun ikut meningkat. Sebagaimana dijelaskan oleh Martono dan Agus Harjito (2007:52) bahwa: 
Return on Equity (ROE) merupakan rasio untuk mengukur tingkat pengembalian investasi pemegang saham. Tingkat pengembalian yang tinggi akan memungkinkan pendapatan yang diharapkan oleh investor akan naik pula dan hal ini akan berdampak pada peningkatan harga saham. Disimpulkan bahwa Return on Equity (ROE) akan mempengaruhi harga saham.

\section{Saham}

Saleh Basir dan H.M. Fakhrudin (2005:11) mendefinisikan saham sebagai berikut :

Saham (Stock) merupakan surat berharga yang menunjukkan kepemilikan seorang investor di dalam suatu perusahaan. Artinya jika seseorang membeli saham suatu perusahaan, berarti dia telah menyertakan modal ke dalam perusahaan tersebut sebanyak jumlah saham yang dibeli. Saham merupaka surat berharga yang dikeluarkan perusahaan dalam rangka menambah modal disetor perusahaan tersebut.

Ada beberapa keuntungan ketika berinvestasi saham diantaranya menurut Taufik Hidayat (2010:85) yaitu:

1. Deviden: merupakan keuntungan yang dibagikan perusahaan dari aktivitas operasionalnya.

2. Capital gain: keuntungan dari hasil selisih harga jual dan beli saham

Selain memperoleh keuntungan, perlu diingat bahwa investasi dalam bentuk saham ini penuh dengan unsur ketidakpastian karena harganya yang sangat fluktuatif sehingga investasi ini juga memiliki tingkat risiko yang besar. Oleh sebab itu, investor juga perlu mengetahui informasi harga saham yang berkembang di bursa efek. Harga saham merupakan indikator nilai perusahaan yang menerbitkannya. Taufik Hidayat (2010:103) ada beberapa jenis harga saham yang harus diketahui ketika memutuskan untuk menjadi investor, yaitu :

1. Harga Nominal: harga yang tercantum pada setiap lembar saham yang diterbitkan oleh perusahaan.

2. Harga Perdana: harga saat pertama kali saham ditawarkan kepada publik saat melakukan penawaran umum perdana atau Initial Public Offering (IPO). 
3. Harga pembukaan (Opening Price): harga yang berlaku saat pertama kali lantai bursa dibuka untuk mulai perdagangan efek pada hari itu.

4. Harga Pasar: harga saham di bursa efek yang terbentuk oleh mekanisme pasar, yaitu permintaan dan penawaran.

5. Harga penutupan: harga yang terbentuk terakhir kali saat bursa ditutup.

Fluktuasi harga saham dipengaruhi oleh banyak faktor. Menurut Mohamad Samsul (2006:200) perubahan harga saham dipengaruhui oleh dua faktor, yaitu:

1. Faktor makro, yaitu :

a. Tingkat bunga umum domestik

b. Tingkat inflasi

c. Peraturan perpajakan

d. Kebijakan khusus pemerintah yang terkait dengan perusahaan tertentu

e. Kurs valuta asing

f. Tingkat bunga pinjaman luar negeri

g. Kondisi perekonomian internasional

h. Siklus ekonomi

i. Faham ekonomi

j. Peredaran uang

2. Faktor mikro

Faktor mikro yaitu faktor yang berkaitan dengan kondisi perusahaan itu sendiri.

Selain itu, menurut Ali Arifin (2007:116) faktor-faktor yang menjadi pemicu berfluktuasinya harga saham adalah:

1. Kondisi fundamental emiten

Faktor fundamental adalah faktor yang berkaitan langsung dengan kinerja emiten itu sendiri. Semakin baik kinerja emiten maka semakin besar pengaruhnya terhadap kenaikan harga saham, begitu juga sebaliknya.

2. Hukum permintaan dan penawaran

Begitu investor tahu kondisi fundamental perusahaan tentunya mereka akan melakukan transaksi baik jual maupun beli. Transaksi ini yang akan mempengaruhi harga saham.

3. Tingkat suku bunga (SBI) 
Perubahan tingkat suku bunga akan mempengaruhi kondisi fundamental perusahaan karena hampir semua perusahaan yang mencatat sahamnya di bursa menikmati pinjaman bank.

4. Valuta asing

Ketika terjadi pergerakan valuta asing misalnya ketika terjadi kenaikan US dolar, para investor akan berbondong-bondong menjual sahamnya untuk ditempatkan di bank dalam bentuk dolar, otomatis harga saham akan menjadi turun.

5. Dana asing di bursa

Jika saham dikuasai oleh investor asing maka kecenderungan saham akan tergantung pada investor asing tersebut.

6. Indeks Harga Saham Gabungan (IHSG)

Jika IHSG naik maka pergerakan harga saham akan cenderung naik, sebaliknya jika IHSG turun maka harga saham akan cenderung turun.

\section{News and rumors}

Yang dimaksud dengan News and rumors disini adalah semua berita yang beredar di tengah masyarakat.

\section{E. Analisis Harga Saham}

1. Analisis Fundamental

Analisis fundamental adalah teknik analisis yang digunakan untuk memperhitungkan nilai dari saham suatu perusahaan di masa mendatang dengan melihat aspek-aspek fundamental yang mempengaruhinya. Dalam skala makro, pendekatan ini melihat kondisi perekonomian dan industri dari perusahaan tersebut. Sedangkan dalam skala mikro pendekatan ini dilakukan dengan menganalisis kondisi perusahaan itu sendiri. Mamduh. M. Hanafi dan Abdul Halim (2007:316) juga mengemukakan:

Analisis fundamental berusaha mencari informasi yang relevan untuk menentukan saham mana yang undervalued (untuk dibeli) serta saham mana yang overvalued (untuk dijual). Informasi yang dimaksud bisa dicari melalui analisis prospek dan risiko yang bisa dilihat melalui data akuntansi, data ekonomi makro, analisis industri, analisis manajemen perusahaan dan analisis lain yang dianggap relevan. 
2. Analisis Teknikal

Menurut Taufik Hidayat (2010:129) "Secara sederhana analisis teknikal dapat diartikan sebagai suatu studi dan seni yang dipakai untuk memahami kecenderungan harga yang akan datang dengan menggunakan chart maupun perhitungan matematis."

\section{KERANGKA PEMIKIRAN}

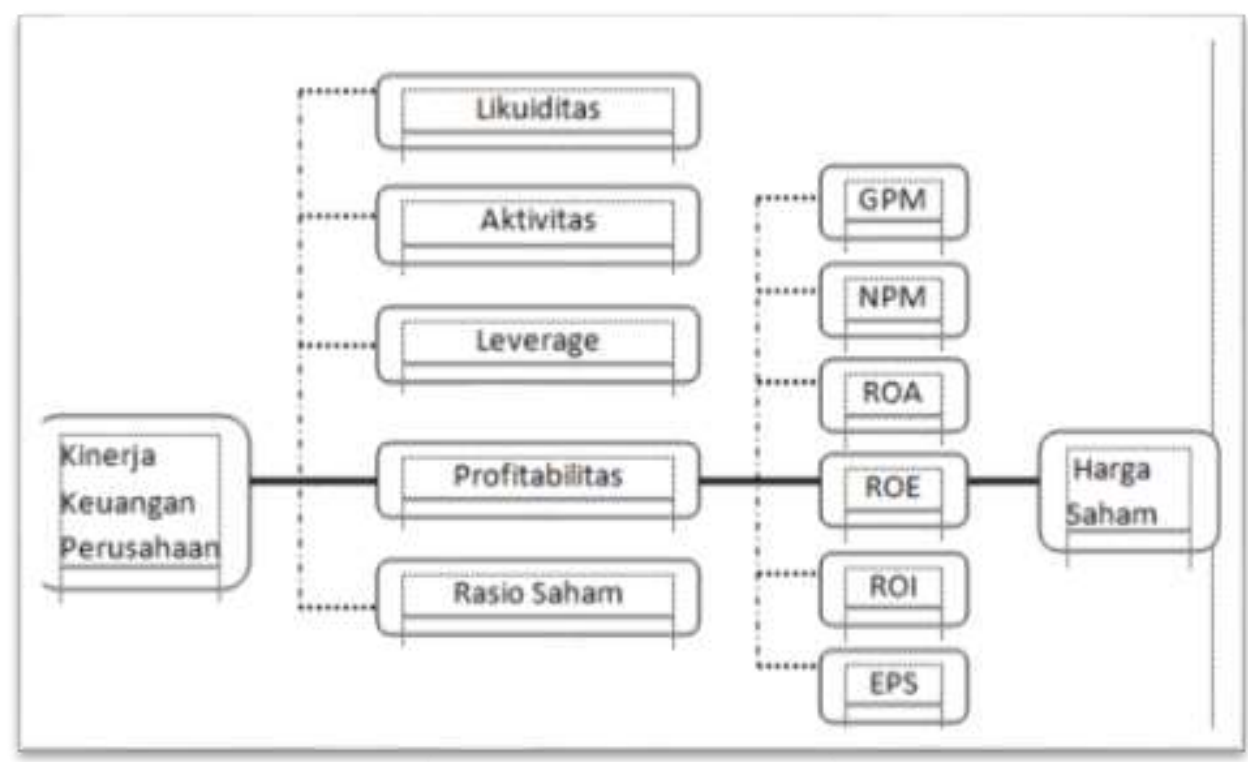

Gambar 2.1

HIPOTESIS

Kerangka Pemikiran

Berdasarkan teori yang telah dikemukakan dan digambarkan dalam kerangka pemikiran, maka hipotesis dalam penelitian ini adalah "Profitabilitas berpengaruh positif terhadap harga saham pada PT Telekomunikasi Indonesia Tbk periode 1998-2011.”

\section{METODE PENELITIAN}

Desain dalam penelitian ini adalah kausal, yaitu untuk mengetahui hubungan antar variabel atau pengaruh suatu variabel terhadap variabel lainnya. Metode yang digunakan adalah deskriptif verifikatif. Metode deskriptif untuk 
menggambarkan variabel yang diteliti. Sedangkan verifikatif bertujuan untuk mengecek kembali kebenaran dari hasil penelitian sebelumnya.

Variabel yang diteliti dalam penelitian ini terdiri dari satu variabel bebas yaitu profitabilitas dan satu variabel terikat yaitu harga saham. Sumber data diperoleh dari laporan keuangan tahunan yang telah dipublikasikan oleh PT Telekomunikasi Indonesia Tbk yang dapat diakses melalui: www.telkom.id. Teknik pengumpulan data dilakukan dengan dokumentasi, artinya peneliti mengumpulkan laporan keuangan PT Telkom untuk dianalisis serta data relevan lainnya.

Teknik analisis data dan pengujian hipotesis dilakukan dengan tahapan sebagai berikut:

1. Menghitung profitabilitas menggunakan indikator ROE dengan rumus:

$$
R O E=\frac{\text { Laba bersih setelah pajak }}{\text { Total Modal Sendiri }} \times 100 \%
$$

2. Uji Linearitas menggunakan P-P Plot

3. Analisis Korelasi Product Moment

4. Menghitung Koefisien Determinasi

Untuk mengetahui kebenaran dari hipotesis yang diajukan, maka terlebih dahulu ditetapkan rancangan pengujian hipotesis yang dinyatakan dalam statistik seperti berikut ini:

Ho $: \rho \leq 0$, artinya profitabilitas tidak berpengaruh positif terhadap harga saham.

Ha $: \rho>0$, artinya profitabilitas berpengaruh positif terhadap harga saham

\section{HASIL DAN PEMBAHASAN}

Hasil penelitian ini menunjukkan bahwa tingkat profitabilitas dengan indikator ROE pada PT Telekomunikasi Indonesia Tbk (Telkom) periode 19982011 berfluktuasi dengan rata-rata bernilai positif, yakni berkisar 30,73\%. Ini mengindikasikan bahwa perusahaan tersebut masih menguntungkan bagi investor. ROE terendah terjadi pada tahun 1998 sebesar 6,94\%. Rendahnya ROE dikarenakan laba yang dihasilkan saat itu sangat rendah, tidak sebanding dengan 
modal yang digunakan untuk menghasilkan laba sehingga dapat dikatakan bahwa pada tahun tersebut perusahaan belum dapat memaksimalkan keuntungan bagi investor yang telah berinvestasi. Secara tidak langsung, rendahnya ROE terjadi akibat adanya krisis ekonomi tahun1997-1998. ROE tertinggi terjadi pada tahun 2002 yakni mencapai 55,02\%. Tingginya ROE pada tahun tersebut dikarenakan belum banyak kompetitor yang masuk dalam industri telekomunikasi serta adanya kenaikan tarif telepon yang memicu naiknya pendapatan perusahaan sehingga menyebabkan kenaikan ROE yang cukup tinggi.

ROE yang dihasilkan Telkom ini beberapa kali mengalami penurunan yaitu di tahun 2003, 2004, 2007, 2008, 2009, 2010, dan 2011. Penurunan ROE yang berlangsung terus menerus tentu akan menimbulkan kekhawatiran bagi pelaku bisnis yang akan berinvestasi karena mengindikasikan kemakmuran yang mereka terima akan berkurang. Penurunan ROE ini menunjukkan bahwa penggunaan modal sendiri untuk mendapatkan laba belum efisien, karena belum dapat memberikan tingkat pengembalian yang maksimal bagi investor.

Kemudian, dari hasil pengamatan lainnya, diperoleh gambaran bahwa harga saham perusahaan juga berfluktuatif. Harga saham tertinggi yang berhasil dicapai oleh perusahaan tercatat di bursa efek pada tahun 2007 sebesar Rp 10.300. Tingginya harga saham ini tidak terlepas dari adanya pengaruh peningkatan ROE pada tahun 2006 sehingga investor merespon positif terhadap kenaikan harga saham. Selain itu, tingginya harga saham saat itu juga di dorong oleh faktor pertumbuhan ekonomi yang terus membaik pasca krisis akibat kenaikan harga BBM tahun 2005. Sedangkan harga saham terendah tercatat pada tahun 1999 sebesar Rp 1.469,91. Hal ini juga tidak terlepas dari pengaruh rendahnya ROE yang dihasilkan pada tahun 1998. Selain itu, krisis keuangan yang terjadi di dalam negeri juga berpengaruh besar terhadap rendahnya harga saham.

Harga saham sempat beberapa kali mengalami penurunan yaitu pada tahun 1999, 2001, 2003, 2008, 2009, dan 2011. Penurunan drastis terjadi pada tahun 2009 yang sedikitnya dipengaruhi oleh penurunan ROE pada tahun 2008. Selain itu, krisis keuangan global di Amerika pada tahun 2008 yang menyebabkan 
melemahnya nilai tukar rupiah terhadap mata uang asing juga menjadi faktor terbesar yang berpengaruh terhadap anjloknya harga saham di bursa efek.

Penurunan harga saham yang drastis pada saat itu telah membuat investor kehilangan kepercayaan untuk menanamkan modalnya, sehingga menyebabkan perusahaan kehilangan salah satu sumber dana tambahannya. Banyaknya investor yang menjual sahamnya kemudian menukar uangnya dengan dolar telah membuat perusahaan mengalami kesulitan untuk memenuhi kebutuhan permodalannya yang akan digunakan untuk membiayai aktivitas operasionalnya. Hal ini menyebabkan permintaan saham menurun dan nilai perusahaan pun ikut menurun.

Penelitian ini bertujuan untuk mengetahui bagaimana pengaruh profitabilitas terhadap harga saham. Berdasarkan hasil uji linearitas, variabelvariabel dalam penelitian ini memiliki hubungan linear dilihat dari sebaran datanya yang berada di sekitar garis normal dan arahnya mengikuti garis diagonal. Kemudian, untuk mengetahui hubungan antara variabel X dan Y maka dilakukan analisis menggunakan teknik korelasi product moment.

Dari tabel penolong yang telah dibuat sebelumnya, diketahui nilai-nilai sebagai berikut:

$$
\begin{aligned}
\Sigma X & =407,28 \\
\Sigma \mathrm{Y} & =66.007,41 \\
\Sigma \mathrm{XY} & =2.188 .883,30 \\
\Sigma \mathrm{X}^{2} & =14.582,96 \\
\Sigma \mathrm{Y}^{2} & =454.201 .104,16
\end{aligned}
$$

Kemudian, untuk mengetahui hubungan antara variabel X (profitabilitas) dan variabel Y (harga saham) dilakukan dengan menghitung koefisien korelasi (r) sebagai berikut:

$$
\begin{aligned}
& r=\frac{n \sum X Y-\sum X \sum Y}{\sqrt{\left\{n \sum X^{2}-\left(\sum X\right)^{2}\right\}\left\{n \sum Y^{2}-\left(\sum Y\right)^{2}\right\}}} \\
& r=\frac{13(2.188 .833,30)-(407,28)(66.007,41)}{\sqrt{\left\{13(14.582,96)-(407,28)^{2}\right\}\left\{13(454.201 .104,16)-(66.007,41)^{2}\right.}} \\
& r=\frac{28.454 .832,91-26.883 .497,94}{\sqrt{(189.578,48-165.876,9984)(5.904 .614 .354-4.356 .978 .175)}}
\end{aligned}
$$




$$
\begin{aligned}
& r=\frac{1.571 .334,96}{\sqrt{(23.701,4816)(1.547 .636 .179)}} \\
& r=\frac{1.571 .334,96}{\sqrt{36.681 .270 .420 .062,8064}} \\
& r=\frac{1.571 .334,96}{6.056 .506,4534} \\
& r=0,25944 \text { dibulatkan menjadi } 0,259
\end{aligned}
$$

Bila diinterpretasikan, angka tersebut bernilai positif sehingga menunjukkan bahwa hubungan antara kedua variabel adalah searah dengan tingkat hubungan yang rendah. Artinya, apabila profitabilitas meningkat maka harga saham akan meningkat. Kemudian untuk mengetahui besarnya pengaruh variabel X terhadap Y maka dilakukan perhitungan koefisien determinasi sebagai berikut:

$$
\begin{aligned}
& k d=r^{2} \times 100 \% \\
& k d=(0,259)^{2} \times 100 \% \\
& k d=0,067081 \times 100 \% \\
& k d=6,7081 \% \text { dibulatkan menjadi } 6,71 \%
\end{aligned}
$$

Berdasarkan hasil perhitungan koefisien determinasi $(\mathrm{kd})$ diketahui bahwa profitabilitas mempengaruhi harga saham sebesar 6,71\% dan sisanya sebesar 93,29\% harga saham dipengaruhi oleh faktor lain diluar profitabilitas seperti permintaan dan penawaran saham, tingkat dan laju inflasi, tingkat suku bunga, nilai kurs yang berlaku, dan informasi lain yang berkembang di pasar bursa yang dengan cepat direspon oleh pelaku pasar.

Dengan demikian, dapat disimpulkan bahwa hipotesis dalam penelitian ini diterima yaitu profitabilitas berpengaruh positif terhadap harga saham. Artinya apabila profitabilitas meningkat maka harga saham akan meningkat. Dan hasil penelitian ini membuktikan bahwa profitabilitas dengan indikator ROE saja ternyata tidak cukup andal untuk dijadikan dasar dalam menganalisis perubahan harga saham yang terjadi di bursa efek dikarenakan pengaruhnya sangat kecil. Dalam penelitian ini, harga saham perusahaan lebih banyak dipengaruhi oleh 
faktor makro seperti krisis keuangan, inflasi yang tinggi, dan kurs valuta asing. Oleh sebab itu, informasi mengenai ROE bukan satu-satunya faktor yang dapat dianalisis dalam memprediksi perubahan harga saham.

\section{KESIMPULAN DAN SARAN}

\section{Kesimpulan}

1. Profitabilitas PT Telekomunikasi Indonesia tbk pada periode 1998-2011 yang diukur dengan rasio ROE berfluktuatif.

2. Harga saham PT Telekomunikasi Indonesia tbk pada periode 1998-2011 berfluktuatif.

3. Dari hasil analisis statistik menggunakan korelasi product moment Pearson menyatakan bahwa antara profitabilitas dan harga saham memiliki hubungan positif dengan derajat hubungan yang rendah. Artinya, apabila profitabilitas meningkat maka harga saham akan meningkat. Dengan demikian hipotesis dalam penelitian ini diterima yaitu profitabilitas berpengaruh positif terhadap harga saham.

\section{Saran}

1. Untuk penelitian selanjutnya, penulis menyarankan agar menggunakan indikator lain dari profitabilitas selain ROE untuk memprediksi harga saham, seperti ROA, ROI, NPM, dan EPS. Jika rasio profitabilitas yang digunakan untuk memprediksi harga saham tidak hanya ROE, melainkan menggunakan rasio profitabilitas lainnya, diharapkan hasilnya dapat memberikan informasi yang lebih beragam bagi pembaca.

2. Penulis juga menyarankan agar peneliti selanjutnya dapat meneliti faktorfaktor lain diluar profitabilitas untuk memprediksi harga saham di bursa efek, mengingat profitabilitas ini memiliki kekuatan hubungan yang rendah terhadap harga saham sehingga pengaruhnya cukup kecil.

\section{DAFTAR PUSTAKA}

Agnes Sawir. (2005). Analisis Kinerja Keuangan dan Perencanaan Keuangan Perusahaan. Jakarta: Gramedia Pustaka Utama 
Agus Sartono. (2009). Manajemen Keuangan Teori dan Aplikasi. Edisi Keempat. Yogyakarta: BPFE

Ali Arifin. (2007). Membaca Saham. Edisi Ketiga. Yogyakarta : ANDI

Bambang Riyanto. (2008). Dasar-Dasar Pembelanjaan Perusahaan. Yogyakarta: BPFE

Husein Umar. (2011). Metode Penelitian Untuk Skripsi dan Tesis. Jakarta: Rajawali Pers

Irham Fahmi dan Yovi Lavianti Hadi (2009). Teori Portofolio dan Analisis Investasi. Bandung: Alfabeta

Iqbal Hasan. (2008). Analisis Data Penelitian dengan Statistik. Jakarta: PT Bumi Aksara

J. Fred Weston dan Eugene F. Brigham. (2005). Manajemen Keuangan. Jakarta: Erlangga

Lukman Syamsuddin. (2009). Manajemen Keuangan Perusahaan. Jakarta: Rajawali Pers

Mamduh. M. Hanafi dan Abdul Halim. (2007). Analisis Laporan Keuangan. Yogyakarta: UPP STIM YKPN

Martono dan Agus Harjito. (2007). Manajemen Keuangan. Yogyakarta : Ekonisia

Moeljadi. (2006). Manajemen Keuangan Pendekatan Kuantitatif dan Kualitatif. Edisi Pertama. Malang: Bayumedia Publishing

Mohamad Samsul. (2006). Pasar Modal \& Manajemen Portofolio. Jakarta: Erlangga

Muhammad Teguh. (2005). Metode Penelitian Ekonomi Teori dan Aplikasi. Jakarta: PT Raja Grafindo Persada.

Pandji Anoraga dan Piji Pakarti. (2008). Pengantar Pasar Modal. Jakarta: Rineka Cipta

Program Studi Pendidikan Akuntansi. (2007). Pedoman Operasional Penulisan Skripsi (POPS). Bandung.

Ridwan S. Sundjaja. (2003). Manajemen Keuangan. Jilid 1. Jakarta: Literata Lintas Media

Rusdin. (2008). Pasar Modal: Teori, Masalah dan Kebijakan dalam Praktik. Bandung: Alfabeta

S. Munawir. (2010). Analisa Laporan Keuangan. Edisi Keempat. Yogyakarta : Liberty

Saleh Basir dan Hendy M. Fakhruddin. (2005). Aksi Korporasi-Strategi Untuk Meningkatkan Nilai Saham Melalui Aksi Korporasi. Jakarta: Salemba Empat

Simamora, Henry. (2000). Akuntansi Basis Pengambilan Keputusan Bisnis Jilid II. Jakarta: Salemba Empat

Suad Husnan. (2005). Dasar-Dasar Teori Portofolio dan Analisis Sekuritas. Yogyakarta: UPP AMP YKPN

Suad Husnan dan Enny Pudjiastuti. (2006). Dasar - Dasar Manajemen Keuangan. Yogyakarta: UPP STIM YKPN

Sudjana. (2004). Statistika Untuk Ekonomi dan Niaga II. Bandung : Tarsito

Sugiyono. (2011). Statistika untuk Penelitian. Bandung : Alfabeta 
Suharsimi Arikunto. (2006). Prosedur Penelitian Suatu Pendekatan Praktik. Edisi Revisi. Jakarta: Rineka Cipta

Susan Irawati. (2006). Manajemen Keuangan. Bandung: Pustaka

Tandelilin, Eduardus. (2010). Portofolio dan Investasi. Yogyakarta: Kanisius

Taufik Hidayat. (2010). Buku Pintar Investasi Reksa Dana, Saham, Opsi Saham, Valas \& Emas. Jakarta: Media Kita.

Tjiptono Darmadji dan Hendy M. Fakhruddin. (2006). Pasar Modal Indonesia. Jakarta: Salemba Empat

Wereen et al. (2005). Akuntansi. Buku Satu Edisi 21. Jakarta: Salemba Empat Jurnal:

Adwin S.Atmaja. (1999). Inflasi di Indonesia : Sumber-Sumber Penyebab dan Pengendaliannya. Jurnal Akuntansi dan Keuangan Vol.1, No.1, 54-67 Tersedia: http://puslit.petra.ac.id/journals/accounting [03 Juni 2012]

\section{Skripsi:}

Lutfi Choeril. (2011). Pengaruh Kinerja Profitabilitas Terhadap Harga Saham PT Indosat Tbk di Bursa Efek Indonesia. Skripsi. Bandung : Universitas Pendidikan Indonesia.

Muchammad Lutfi. (2011). Pengaruh Return on Equity Terhadap Harga Saham PT Bakrieland Development Tbk di Bursa Efek Indonesia. Skripsi. Bandung: Universitas Pendidikan Indonesia.

Rasyid Setiansyah. (2012). Pengaruh Profitabilitas Terhadap Harga Saham Perusahaan Tekstil di Bursa Efek Indonesia Periode 2006-2010. Skripsi. Bandung : Universitas Pendidikan Indonesia.

Internet :

(2010). Daftar Kapitalisasi Pasar \& Saham 2010: TLKM No.3 Tergusur oleh ASII \& BBCA. Tersedia: galerisaham.com/2010/.../daftar-kapitalisasi-pasar-saham-2010-tlkm... [online] 3 Juli 2012

(2011). Special Report: Akankah Saham Berkapitalisasi Besar Mendukung Kenaikan IHSG? Tersedia: http://galerisaham.com/2011/12/21/special-report-akankah-sahamberkapitalisasi-besar-mendukung-kenaikan-ihsg/ [online] 3 Juli 2012

Arinto Tri Wibowo. (2011). Kapitalisasi Pasar Telkom Makin Tergeser. Tersedia:http://bisnis.vivanews.com/.../241508-kapitalisasi-pasartelkom-makin-terg... [online] 3 Juli 2012

Badan Pusat Statistik (BPS) No. 10/02/Th.XI. (2008). Berita Resmi Statistik. [online]. Tersedia: http://www.bps.go.id/getfile.php?news=597 [02 Juni 2012]

Burhanuddin. (2003). Peran Kebijakan Moneter dan Perbankan dalam Mengatasi Krisis Ekonomi di Indonesia. [online]. Tersedia: http://www.bi.go.id/biweb/html/sambutan-13-2003-gbi.pdf. [02 Juni 2012]

Bursa Efek Indonesia. Undang-Undang Pasar Modal No. 8 Tahun 1995. [online].Tersedia: 
http://www.bapepam.go.id/.../files/.../uu_no_8_tahun_1995_pasar_mo dal...[14 Juni 2012]

Dampak Krisis Keuangan Global. (2008). [online]. Tersedia: http://rutacs.wordpress.com/2008/.../dampak-krisis-keuangan-global [03 Juni 2012]

Data Laporan Keuangan PT Telekomunikasi Indonesia Tbk. (2011). [online]. Tersedia: http://www.telkom.co.id [12 Maret 2012]

Profil PT Telekomunikasi Indonesia Tbk. (2011). [online]. Tersedia: http://www.telkom.co.id [12 Maret 2012] 